\title{
THE STUDY OF HAEMATOLOGICAL PARAMETERS IN THE NIGERIAN LOCAL CHICKEN
}

\author{
F.U.C. MMEREOLE \\ Department of Animal Science, Delta State University, Anwai Campus, Asaba. Nigeria. \\ Received 24 March, 1994; Accepted 26 May, 1996
}

\begin{abstract}
$A^{n}$ investigation was conducted to study the haematological parameters of the Nigerian local chicken using a total of 100 local chickens out of which 30 were randomly selected for bleeding. The blood samples were subjected to laboratory analysis to identify their haemoglobin contents, fragility and sedimentation rates as well as red blood cell counts, white blood cell counts and coagulation time. The results indicated that haemoglobin content ranged from $63.82-78,43 \%$ with a mean of $70.43 \%$, fragility and sedimentation rates ranged from $0.40-0.55 \%$ osmotic equivalent, coagulation time from 3.82 - 6.25 minutes with a mean of 4.61 minutes, the red blood cell counts from $1.93-2.96\left(\times 10^{6} / \mathrm{ul}\right)$ with a mean of 2.5 $(\mathrm{x10} / \mathrm{ul})$ and white blood cell counts from 962 . 1,868 cells/ul with a mean of 1,216 cells/ul. It is believed that the establishment of the normal blood characteristics of the local chicken as done in this study, can be of immense aid in detecting abnormalities in the blood characteristics which can be used in diagnosing certain blood related diseases.

Keywords: Chicken, Blood parameters,
\end{abstract}

\section{INTRODUCTION}

One of the primary functions of haematological studies is to apply the knowledge of the blood characteristics to detect various blood diseases and the effects of the non-blood diseases on the blood. Onyeyili (et al., 1991) stressed on the importance of haematological evaluation in poultry as a valuable aid in the diagnosis of many diseases and in determing the extent of damage to blood cells. Woerpel and Rosskppf (1984) further emphasised, the need for haematological indices in evaluating the responses of the animal to therapy. In addition, the knowledge of the blood characteristics in local chicken, like many other livestock, will assist in associating certrin inherent resistance to infections with certain blood characteristics (Deaton et al, 1970 Anosa and Isoun, 1978). Such studies will give effective guidelines on blood transfusion, breeding programmes for disease resistance, the control and/or treatment of certain diseases associated with blood disorders. Consequently, the study was designed to:

i. determine the normal total blood counts;

ii. estimate the haemoglobin content and thus the oxygen carrying capacity of the blood;

iii determine the erythrocyte sedimentation and fragility rates in the local chicken and

iv. suggest a possible characterization of the local chicken with respect to the blood characteristics.

\section{MATERIALS AND METHODS:}

A total of 100 local chicken's were involved in the experiment. The $\mathbf{1 0 0}$ local chickens were placed on the same nutritional plane using commercial growers mash with the composition: M.E. - 2,900 Kcal/kg; Protein $16 \%$; Lysine - 0.9\%; Methionine - 0.6\%; Premix.- $1.5 \%$

On arrival, the birds were dewormed with Piperazine at an oral dose of $50 \mathrm{mg} / \mathrm{kg}$ body weight. They were also prophylactically treated against coccidiosis using Amprolium. To rule out any incidence of respiratory disease, they were treated with Neo-terramycin soluble powder. After 4 weeks, the birds were physically examined to ensure that the blood samples were obtained from birds without any disease complications.

At the end of 4 weeks, 30 local chickens were randomly selected and blood samples 
obtrined from them via the wing veins using disodium ethylenediamine tetracetate (EDTA) as the anticongulant. The blood samples wete sent to the dismostic laboratory to determine the haemoglobin content (HB), the red blood and white blood counts, using the method of Brown (1976). The sedimentation and fragility tests were carried out using the standard procedure (Schalm et al,; 1975) and then calculated in percentage osmotic equivalent. To determine the coagulation time, the different blood samples were put in the tests tubes and left to clot. The time taken for each sample to clot was noted. ranges from $63.82-78.43 \%$ with a mean of $70.43 \%$. This result compares very well with the range of $65-75 \%$ in the exotic chickens as reported by Oyewole and Ogwuegbu (1986). The aim of estimating the haemoglobin content is to determine the oxygen carrying capacity of the birds circulatory system. The birds with $\mathrm{Hb}$ contents that fall below $60 \%$ have low oxygen carrying capacity and this is an indication that such birds can easily succumb to any form of respiratory disease while the birds with $\mathrm{Hb}$ concentrations exceeding $60 \%$ can be regarded as having high oxygen carrying capacity. Such birds are likely

TABLE 1: HAEMOGLOBIN CONTENT (HB); RED BLOOD CELLS (RBC) WHITE BLOOD CELL COUNTS (WBC) FRAGILITY AND SEDIMENTATION ON RATES (FSR) IN PERCENTAGE OSMOTIC EQUIVALENT AND COAGULATION TIME

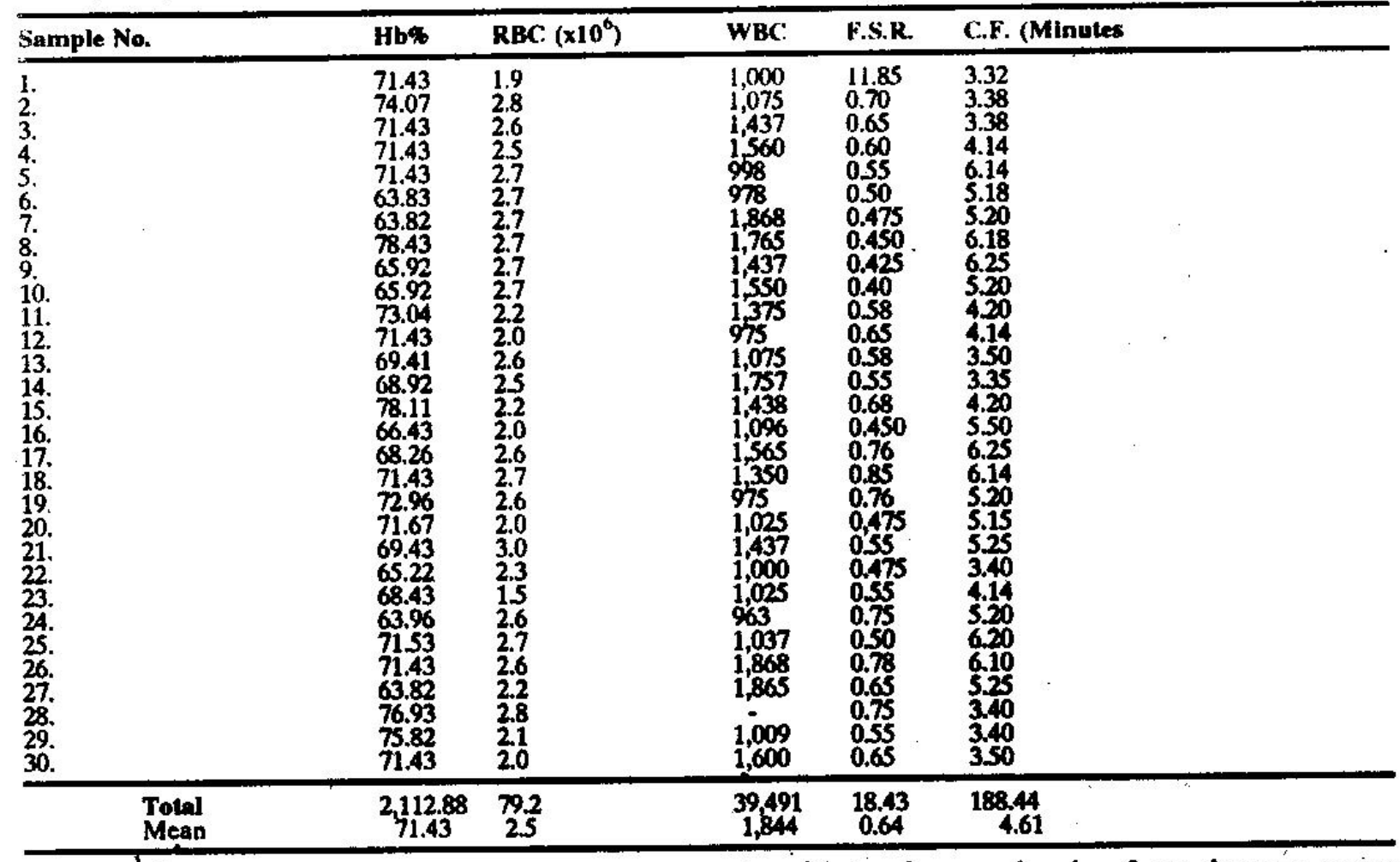

\section{RESULTS AND DISCUSSION:}

Table 1 shows the results of the laboratory analyses of the blood samples with respect to the haemoglobin contents, red blood cell counts, white blood cell counts, fraqility and sedimentation rates (expressed as percentage osmotic equivalent) and coagulation time of the blood. From the data, it can be observed that the percentage haemoglobin content to withstand some levels of respiratory stress (Salisbury, 1983).

The data on the haematological indices also indicate that the fragility and sedimentation rates showed a range of $0.40-0.85$ percentage osmotic equivalents while Gilbert (1962) and Vanley (1969) established a normal range for the exotic chickens as $0.39-0.55$ percentage osmotic equivalent. The knowledge of fragility rates in birds may be of immense aid in clinical 


\section{HEAMATOLOGICAL STUDIES IN LOCAL CHICKENS}

diagnosis. The sedimentation and fragility rates are higher in birds with certain infections than in healthy birds (Woerpel and Rosskopf, 1984).

From the data in Table 1, the elotting or coagulation time in the local chickens ranged from 3.82 - 6.25 minutes while Gilbert (1969) established a range of 5 - 10 minutes for the exotic birds. Variations occur in the clotting time of chickens as a result of certain factors. These variations range from absence of clotting as in the case of haemophilia to delayed clotting as in the case of certain infections. Cases of certain levels of delayed clotting or reduced clotting when associated with certain disease conditions can aid in diagnostic processes. (Apata and Adeleye, 1983; Oyewole and Ogwuegbu, 1986 and Isegbe and Ubosi, 1993).

The results of the analysis also indicated that the red blood cells counts ranged from 1.93 to $2.96\left(\times 10^{6} / \mathrm{ul}\right)$. However, wintrobe (1993) established a mean of $2.00\left(\times 10^{6} / \mathrm{ul}\right)$ for the exotic chickens. To this extent, the local chickens exhibit. superiority over their exotic counterparts. Since the red blood cells carry the respiratory pigments - the haemoglobin, a decrease in the quantity of the circulating red blood cells would also imply a decrease in the quantity of haemoglobin and thus a decrease in the oxygen - carrying capacity of the birds. This of course, indicates that the birds will easily succumb to any condition that will generate a serious respiratory distress.

With respect to the white blood cell counts, the result showed a range of $962 \cdot 1,868$ cells per cubic millimeter with a mean of 1,216 cells per cubic millimeter while Schalm et al. (1975) and Wintrobe (1983) reported $450-500$ cells per cubic millimeter for the exotic chickens. This range, again, is far below that obtained for the Nigerian Local Chicken. The white blood cells (leucocytes) play prominent role in disease resistance especially with respect to the generation of antibodies and the process of phagocytosis. This may explain the reason for the high degree of disease resistance which many studies have reported for the Nigerian Local Chicken (Nwosu, 1979; Omeje, 1983;
Mmreole, 1985 and Anyanwu and Adikuru, 1993).

Haematological parameters collected from this study can be used to establish the normal blood characteristics of the Nigerian Local Chickens with respect to the haemoglobin content, red and white blood cell counts, fragility and sedimentation rates and the coagulation or clotting quality of the blood. The establishment of these normal blood characteristics may be of immense aid in detecting the abnormalities in the blood characteristics which may be associated with certain disease conditions. Such information can be utilized in the control and/or treatment of such blood diseases as coronary thrombosis and avian lenkosis complex.

\section{REFERENCES}

ANOSA, V.O. and ISOUN, T.T. (1978) Haematological Studies on domestic animals in Nigeria. Factors influencing haematocrit of sheep and goats. Zentrolblatt fur Veterinary Medizin. 4: 25

APATA, D.F. and ADELEYE, F.A (1983). Haematological and biochemical characteristics of growing broiler chickens fed raw and processed pigeon peas (Cajanus cajan). Book of Abstr. Nig. Society for Animal Production 18th Annual Conference, 1993

ANYANWU, G.A. and ADIKURU, C.O. (1993). Biometric measurements of the local chicken and the effect of release age on the extensively managed exotic cockrels. The Book of Abstr. Nig. Society For Animal Production, 18th Annual Conference, 1993 Owerri.

BROWN, B.A. (1976) Haematology: Principles and Procedures 2nd Ed. Lea and Fabinger, Philadephia.

DEATON, J.W.; REECEN, F.N. and TRAVER, W.I. (1970). Haematocrit, haemoglobin and plasma protein levels of broilers under constant temperature. Poultry Science. 48: 1683 - 1686.

GILBERT, A.B. (1962). Sedimentation rate of erythrocytes in the domestic cock. Poultry 
Science: 41: 784 - 788 .

GILBERT, A.B. (1969) Erythrocyte Sedimentation rate and packed cell volume in the domestic food. Brit. Poultry Science 9: 297 - 299

ISEGBE, V.I. and UBOSI, C.O. (1993). Effect of different Management System on haematology and humoral response to sheep erythrocyte in local ducks. Book of Abstr. The Nig. Society for Animal Production, 18th Annual Conference. Owerri. March.

MMEREOLE, F.U.C. (1985). Genotype X Diet Interactions in the body Weight of the Nigerian Local Chicken and its crosses with the Barred Plymouth Rocks. M.Sc. Thesis, Department of Animal Seience, Univeristy of Nigeria, Nsukka.

NWOSU, C.C. (1979). Characterisation of the local chicken of Nigeria and its potential for egg and meat production. Proc. of the lst National Seminar on Poultry Production in Nigeria. pp. 187 - 210.

OMEJE, S.S.I. (1993). Heterosis of the body weight and short-term egg production in crosses between parent stock of Gold-link and the Nigerian Local Chicken. M.Sc. Thesis, Faculty of Agriculture, University of Nigeria. Nsukka.
ONYEYILI, P.A.; EGWU, G.O. JIBIKE, G.I.; PEPPLE, D. J. and CHAEGBULAM, J.O. (1991). Seasonal Variations in haematological indices in the grey-breasted Guinea fowls (Numida meleagris Gallata pallas) Nig. Journal of Animal Prod. 18(2): 108 - 111.

OYEWOLE, J.O. and OGWUEGBU, S.O. (1986) Haematological studies in the Guinea fowl. Bull Animal Health Prod. Africa. 34:6165.

SALISBURY, D. (1983) Animal Health. Ist Edition, Granada Publication Limited; New,. York, U.S.A.

SCHALM, O.W., JAIN, N.C. and CARROLL, E.J. (1975); Veterinary Haematoloty, 3rd Edition, Lea and Fabinger Philadephia.

VANLEY, H. (1963) Practical Clinical Chemistry 3rd Edition, Churchill, London.

WINTROBE, M.N. (1983). Clinical Haematology, 4th Edition Pitman Books Limited London.

WOERPEL, R.W. and ROSSKOPF, W.J. Jr. (1984). Avian Haematology, Veterinary Clinics of North American Small Animal practice 14: 249-258. 